\title{
The Contribution from Shipping Emissions to Air Quality and Acid Deposition in Europe
}

\begin{abstract}
A global three-dimensional Lagrangian chemistry-transport model STOCHEM is used to describe the European regional acid deposition and ozone air quality impacts along the Atlantic Ocean seaboard of Europe, from the $\mathrm{SO}_{2}, \mathrm{NO}_{x}$, VOCs and $\mathrm{CO}$ emissions from international shipping under conditions appropriate to the year 2000. Model-derived total sulfur deposition from international shipping reaches over $200 \mathrm{mg} \mathrm{S} \mathrm{m}^{-2} \mathrm{yr}^{-1}$ over the southwestern approaches to the British Isles and Brittany. The contribution from international shipping to surface ozone concentrations during the summertime, peaks at about $6 \mathrm{ppb}$ over Ireland, Brittany and Portugal. Shipping emissions act as an external influence on acid deposition and ozone air quality within Europe and may require control actions in the future if strict deposition and air quality targets are to be met.
\end{abstract}

\section{INTRODUCTION}

Policy-makers have raised concerns about acidification, eutrophication and ground-level ozone in Europe. International agreements have been promulgated within the United $\mathrm{Na}-$ tions Economic Commission (UN ECE) in its Gothenburg Protocol and within the European Union (EU) in its National Emissions Ceilings Directive to control and reduce air pollution problems within Europe. These agreements have the long-term aim of reducing European emissions from human activities, as far as possible, to protect the environment from acidification and eutrophication and to reduce exposures to ground-level ozone. However, not all the damaging emissions that lead to deterioration in Europe's air quality and deposition come under the policy influence of the UN ECE and EU. Some of the emissions arise beyond the geographical or policy influence of these two bodies. As European emissions are progressively controlled, sources outside of the European sphere of control will make a proportionately larger contribution to future critical levels and loads exceedance.

In this study, the influence of international shipping emissions on acid deposition and ozone air quality in Europe is studied using a global three-dimensional Lagrangian chemistry-transport model, STOCHEM. Previously, using this model, we have identified the role of intercontinental transport of ozone as a potential external influence on Europe's air quality (1). Sales of marine diesel oil to international shipping, so-called bunkers, are not attributed to individual countries or regional groupings and so are not included in the emission inventories compiled by the UN ECE and EU and do not come under the aegis of the Kyoto Protocol to the United Nations Framework Convention on Climate Change.
Here, we show that the contributions to acid deposition and ozone air quality on the western fringes of Europe resulting from the sulfur dioxide $\left(\mathrm{SO}_{2}\right)$ and nitrogen oxides $\left(\mathrm{NO}_{\mathrm{x}}\right)$ emissions arising from international shipping are currently not negligible. Without emission controls, they will become increasingly important, while European land-based $\mathrm{SO}_{2}$ and $\mathrm{NO}_{\mathrm{x}}$ emissions are being progressively controlled.

Several reports have drawn attention to ship emissions as a source of $\mathrm{NO}_{\mathrm{x}}$ and $\mathrm{SO}_{2}$ emissions $(2,3)$ and it is now recognized that ship emissions have global, regional and local impacts. Lawrence and Crutzen (4) studied the effects of shipping on tropospheric ozone, hydroxyl radicals and methane lifetimes. Capaldo et al. (5) reported on the impact of shipping emissions on the biogeochemical cycling of sulfur compounds. Jonson et al. (6) described the effects of shipping emissions on acidification, eutrophication, and ground-level ozone formation in Europe. Endresen et al. (7) quantified the shipping contribution to global emissions of $\mathrm{NO}_{\mathrm{x}}, \mathrm{SO}_{2}, \mathrm{CO}, \mathrm{CO}_{2}$ and VOCs and reported maximum perturbations in ozone of up to $10 \mathrm{ppb}$ in the North Atlantic Ocean and a 3-10\% increase in acidification due to shipping. During the year 2000, the European shipping fleet emitted just over $2.5 \mathrm{Tg} \mathrm{SO}_{2} \mathrm{yr}^{-1}$ compared with just under $5.8 \mathrm{Tg}$ $\mathrm{SO}_{2} \mathrm{yr}^{-1}$ from land-based sources (8). It is likely that ship emissions will play a progressively more important role in achieving regional and global environmental policy targets in the future as land-based emissions are further controlled.

\section{THE CHEMISTRY-TRANSPORT MODEL}

The deposition of acidic substances and regional air quality were quantified using a global Lagrangian chemistry-transport model STOCHEM (9). This model describes atmospheric chemical processes using a number of air parcels that are transported around the globe using meteorological fields. The air parcels pick up emissions when they are advected into the atmospheric boundary layer. Chemical processes involving the emitted sulfur dioxide and oxides of nitrogen, generate acidic substances that are removed by wet and dry deposition processes. Further, sunlight-driven photochemical reactions involving the ozone precursor species: nitrogen oxides, methane, carbon monoxide and organic compounds, result in the formation of ozone.

Ozone itself is subsequently removed by dry deposition to the earth's surface.

STOCHEM was used to carry out the series of numerical experiments investigating acid deposition and regional air quality in Europe and its coupling to the global scale. This chemistry-transport model received meteorological fields from a driving climate model, but chemical fields were not 


\begin{tabular}{|c|c|c|c|c|c|c|c|}
\hline Trace Gas & Total & Anthropogenic & $\begin{array}{l}\text { Biomass } \\
\text { burning }\end{array}$ & Vegetation & Soil & Ocean & Other Natural \\
\hline NO & 49.6 & $\begin{array}{l}27.4^{a} \\
0.7^{\mathrm{a}} \text { (aircraft) }\end{array}$ & 8.2 & & 5.6 & & $\begin{array}{l}7.3^{\mathrm{b}} \text { (Lightning) } \\
\sim 0.4^{\mathrm{b}} \text { (Stratosphere) }\end{array}$ \\
\hline $\mathrm{CO}$ & 1114 & 492 & 537 & 35 & & 50 & \\
\hline $\mathrm{CH}_{4}$ & 578 & 253 & 74 & 27c (Termites & & 13 & $211^{d}$ (Wetlands) \\
\hline $\mathrm{C}_{2} \mathrm{H}_{6}^{4}$ & 14.9 & 9.6 & 4.1 & 1.2 & & & \\
\hline $\mathrm{C}_{3} \mathrm{H}_{8}$ & 13.0 & 11.3 & 1.2 & 0.5 & & & \\
\hline $\mathrm{C}_{4} \mathrm{H}_{10}$ & 81.9 & 78.8 & 1.9 & 1.2 & & & \\
\hline $\mathrm{C}_{2} \mathrm{H}_{4}$ & 22.3 & 10.7 & 8.5 & 3.1 & & & \\
\hline $\mathrm{C}_{3} \mathrm{H}_{6}$ & 22.9 & 12.7 & 8.5 & 1.7 & & & \\
\hline $\mathrm{CH}_{3} \mathrm{OH}$ & 11.2 & 6.5 & 4.7 & & & & \\
\hline $\mathrm{HCHO}$ & 1.7 & 1.0 & 0.7 & & & & \\
\hline $\mathrm{CH}_{3} \mathrm{CHO}$ & 6.9 & 3.3 & 3.6 & & & & \\
\hline Acetone & 7.3 & 3.9 & 0.5 & 2.9 & & & \\
\hline O-Xylene & 16.4 & 15.1 & 1.3 & & & & \\
\hline Toluene & 24.2 & 16.2 & 8.0 & & & & \\
\hline Isoprene & 575 & & & $575^{\mathrm{b}}$ & & & \\
\hline Terpene & 191 & & & $191^{b}$ & & & \\
\hline $\mathrm{H}_{2}{ }^{\mathrm{e}}$ & 48 & 20 & 20 & & 4.0 & 4.0 & \\
\hline $\mathrm{SO}_{2}$ & 79.9 & 65.8 & 5.1 & & & & 9.0 (Volcanoes) \\
\hline DMS & 16 & & & & 1.0 & 15.0 & \\
\hline $\mathrm{NH}_{3}{ }^{\mathrm{f}}$ & 53.6 & 39.4 & 3.5 & & 2.5 & 8.2 & \\
\hline \multicolumn{8}{|l|}{ Notes: } \\
\hline \multicolumn{8}{|c|}{${ }^{a}$ Aircraft emissions from Henderson et al. (20). } \\
\hline \multicolumn{8}{|c|}{$\begin{array}{l}{ }^{\mathrm{b}} \mathrm{NO} \text { from lightning and the stratosphere (added as } \mathrm{HNO}_{3} \text { ), and isoprene and terpene from vegetation (10) are calculated interactively. } \\
{ }^{\mathrm{C}} \mathrm{CH}_{4} \text { emissions from termites (Sanderson, 1996) utilize the vegetation emissions distribution. }\end{array}$} \\
\hline \multirow{2}{*}{\multicolumn{8}{|c|}{$\begin{array}{l}{ }^{\mathrm{d}} \mathrm{CH}_{4} \text { emissions from wetlands use the distribution from Aselmann and Crutzen (1989), and have been scaled upwards so that the modeled global } \\
\mathrm{CH}_{4} \text { trend in the early } 1990 \text { s approximately matches observations. }\end{array}$}} \\
\hline & & & & & & & \\
\hline \multirow{2}{*}{\multicolumn{8}{|c|}{${ }^{\mathrm{e}} \mathrm{H}_{2}$ emissions are from Sanderson et al. (10). }} \\
\hline${ }^{1} \mathrm{NH}_{3}$ emissio & from EDG & i v2.0 (24). & & & & & \\
\hline
\end{tabular}

fed back into the radiation scheme of the climate model in the experiments described here. The model version used was essentially the same as that described by Sanderson et al. (10), although some of the boundary conditions and emissions differed slightly. A brief description of the main model components follows.

\section{The Driving Climate Model: HadAM3}

The Hadley Centre climate model (HadAM3) (11) is a general circulation model describing the atmosphere only and in the version employed here used a prescribed sea surface temperature climatology (1978-1996) from the Atmospheric Model Inter-comparison Project II, (12) to provide the lower boundary condition over the oceans. Over land, a surface exchange scheme was used (13), together with a prescribed seasonal vegetation distribution. Surface characteristics were used to drive dry deposition uptake and vegetation emissions of several species in STOCHEM (10). HadAM3 was run at standard climate resolution: $3.75^{\circ}$ longitude $\mathrm{x}$ $2.5^{\circ}$ latitude, with 19 vertical levels, concentrated towards the surface, and extending upwards to $\sim 10 \mathrm{hPa}$. The model time-step was 30 minutes, with meteorological fields passed to STOCHEM every 3 hours.

\section{Chemistry Sub-model: STOCHEM}

STOCHEM is a Lagrangian tropospheric chemistry-transport model, originally described by Collins et al. (9), with subsequent major updates to chemistry, convective mixing, surface deposition and vegetation emissions (10). Brief descriptions of the main components are given below.

The STOCHEM model extends from the surface up to $\sim 100 \mathrm{hPa}$. Within this domain, the atmosphere is divided into 50000 equal mass air parcels, which are advected us- ing winds from HadAM3, using a fourth order Runge-Kutta method. For every 1 hour advection time-step, winds are linearly interpolated to each parcel's position in the horizontal, and using cubic interpolation in the vertical. A random walk component is added to simulate horizontal and vertical diffusion. Following each advection step, air parcels are mapped to an Eulerian grid of dimensions $5^{\circ} \times 5^{\circ}$ with nine equally spaced vertical levels, of thickness $\sim 100 \mathrm{hPa}$. To represent the deformation of air parcels, some inter-parcel mixing is implemented between air parcels within the same Eulerian grid volume. Air parcel concentrations are brought towards the mean value for the grid volume. Turbulent mixing in the boundary layer is achieved by randomly re-assigning the vertical coordinates of air parcels over the depth of the layer. Convective mixing is described fully in Collins et al. (14), and utilizes 3-D convective diagnostics from the climate model, including updraught and detrainment mass fluxes.

Global trace-gas sources by species, are given in Table 1 for the year 2000. Anthropogenic (totals and distributions), biomass burning (totals only) and vegetation (totals only) emissions were taken from the IIASA 'business as usual' scenario (15). The European emissions and their underlying assumptions are extensively described elsewhere (16). Biomass burning totals were doubled, to bring them approximately in line with IPCC (17) estimates, while spatial and seasonal distributions were taken from Cooke and Wilson (18). Vegetation emissions of isoprene and terpene were distributed using spatial vegetation fields from the land surface scheme of the driving climate model which for isoprene included a dependence upon temperature and photosynthetically available radiation (10). Interactive lightning $\mathrm{NO}_{x}$ emissions were based on Price et al. (19) and Meijer et al. (20) and totalled $\sim 7.3 \mathrm{Tg}(\mathrm{N}) \mathrm{yr}^{-1}$. Aircraft emissions were based on the NASA 1992 inventory (21) updated to 2000. Shipping emissions are described in detail below. 
The chemical scheme includes 70 species that take part in 174 photochemical, gas-phase, and aqueous-phase reactions and equilibria. The mechanism describes the tropospheric chemistry of methane, carbon monoxide, $\mathrm{NO}_{\mathrm{x}}, \mathrm{O}_{3}$, and 11 non-methane hydrocarbons. All species were transported and the chemical time-step was 5 minutes. The updated dry deposition scheme is described in Sanderson et al. (10). The wet deposition scheme remains unchanged, and is described in detail by Stevenson et al. (22). The top of the chemistry model was set at $\sim 100 \mathrm{hPa}(\sim 14 \mathrm{~km})$. To represent the influx of stratospheric $\mathrm{O}_{3}$ to the model domain, vertical wind fields at $100 \mathrm{hPa}$ were used and were coupled up with an ozone climatology (23). Similarly, total oxidized nitrogen influx (as $\mathrm{HNO}_{3}$ ) was introduced assuming a fixed mass ratio of $\mathrm{N}: \mathrm{O}_{3}$ of $1: 1000(24)$.

\section{International Shipping Emissions}

The global emission inventories utilized in STOCHEM for methane, $\mathrm{SO}_{2}, \mathrm{NO}_{\mathrm{x}}$, VOCs and $\mathrm{CO}$, and described above included a contribution from international shipping at a spatial resolution of $1^{\circ}$ latitude $\mathrm{x} 1^{\circ}$ longitude (redistributed to $5^{\circ} \times 5^{\circ}$ for use in the model), based on EDGAR v3.2 data for 1995 (25). The total $\mathrm{SO}_{2}$ and $\mathrm{NO}_{\mathrm{x}}$ emissions from international shipping for each year from 1990 through to 2010 were obtained from the 1995 values using an assumed growth rate of $+1.25 \% \mathrm{yr}^{-1}$ independent of location. In this way, total $\mathrm{SO}_{2}$ and $\mathrm{NO}_{x}$ emissions for the year 2000 of $7.8 \mathrm{Tg} \mathrm{SO}_{2} \mathrm{yr}^{-1}$ and $10.2 \mathrm{Tg} \mathrm{NO}_{\mathrm{x}}$ as $\mathrm{NO}_{2} \mathrm{yr}^{-1}$, respectively, were obtained in approximate agreement with those of $8.48 \mathrm{Tg} \mathrm{SO}_{2} \mathrm{yr}^{-1}$ and $10.12 \mathrm{Tg} \mathrm{NO}_{\mathrm{x}}$ as $\mathrm{NO}_{2} \mathrm{yr}^{-1}$, reported by Corbett et al. (3). Corbett and Koehler (26) and Endresen et al. (7) provide cogent evidence that the spatial distribution of shipping emissions is currently poorly quantified. Furthermore, total emissions may be underestimated by up to a factor of 2 (26). In the absence of updated spatially allocated emission inventories, that from EDGAR v3.2 has been retained in this study.
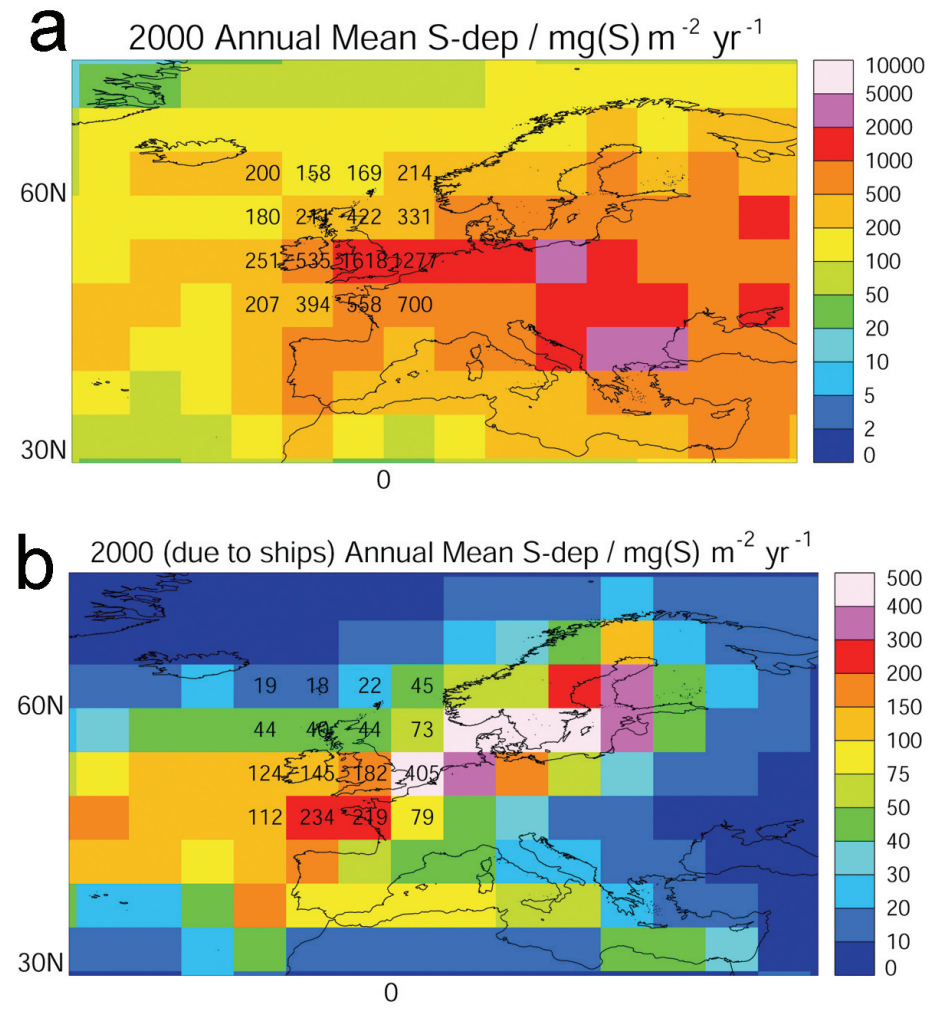

Figure 1. The annual sulfur deposition field in $\mathrm{mg} \mathrm{S} \mathrm{m}^{-2} \mathrm{yr}^{-1}$ for 2000 from a) all man-made and natural sources; and b) from international shipping alone.

\section{ACID DEPOSITION FROM INTERNATIONAL SHIPPING}

In previous studies, we have quantified the global sulfate aerosol and sulfur deposition fields in STOCHEM (27). By running the model with and without international shipping emissions, the contribution from international shipping has been quantified. The spatial distribution of the sulfur deposition from shipping agrees closely with that reported by Endresen et al. (7). Focussing on the Atlantic Ocean seaboard of Europe, the sulfur deposition field for the year 2000 generated by STOCHEM, from all sulfur sources both manmade and natural, is shown in Figure 1a, with Figure 1b showing the contribution from international shipping. The model calculated fields include both wet and dry deposition of both $\mathrm{SO}_{2}$ and particulate sulfate.

Model total sulfur deposition from all sources peaks in central Europe (Fig.1a) with a maximum deposition of over $2000 \mathrm{mg} \mathrm{S} \mathrm{m}^{-2} \mathrm{yr}^{-1}$. A ridge of high deposition above 1000 $\mathrm{mg} \mathrm{S} \mathrm{m}^{-2} \mathrm{yr}^{-1}$ extends towards the British Isles from central Europe, leading to peak deposition over the United Kingdom in excess of $1600 \mathrm{mg} \mathrm{S} \mathrm{m}^{-2} \mathrm{yr}^{-1}$. Total annual sulfur deposition over the United Kingdom amounts to $0.26 \mathrm{Tg} \mathrm{S}$. The Atlantic Ocean seaboard of Norway, Scotland, Ireland, France, Spain, and Portugal receives total sulfur deposition amounts in the range of $200-500 \mathrm{mg} \mathrm{S} \mathrm{m}^{-2} \mathrm{yr}^{-1}$.

In comparison, the observed total sulfur deposition to the UK amounts to $0.23 \mathrm{Tg} \mathrm{S} \mathrm{yr}^{-1}$ (in 1997) and shows a spatial distribution with a broad maximum of over $1400 \mathrm{mg} \mathrm{S} \mathrm{m}^{-2}$ $\mathrm{yr}^{-1}$ across northern England, falling off to $600 \mathrm{mg} \mathrm{S} \mathrm{m}^{-2}$ $\mathrm{yr}^{-1}$ in the more remote parts of Scotland (28). The model sulfur deposition fields over the British Isles therefore agree closely in magnitude and spatial distribution with the observations. Observed wet sulfur deposition amounts at monitoring stations on the Atlantic Ocean seaboard are found to lie in the range from $117-532 \mathrm{mg} \mathrm{S} \mathrm{m}^{-2} \mathrm{yr}^{-1}$ (29). Model sulfur deposition fields along the coastal fringes of Europe also, therefore, agree with observations.

The model total sulfur deposition field shows the presence of a finger of increased deposition passing across the Atlantic Ocean corresponding to the deposition contour of $200-500$ $\mathrm{mg} \mathrm{S} \mathrm{m}{ }^{-2} \mathrm{yr}^{-1}$. In the western fringes of the United Kingdom, the total sulfur deposition in air masses crossing the North Atlantic Ocean appears to be $150-250 \mathrm{mg} \mathrm{S} \mathrm{m}^{-2} \mathrm{yr}^{-1}$. Sulfur deposition at this magnitude would lead to sulfate in precipitation concentrations of about $10-15 \mu \mathrm{eq} \mathrm{SO} \mathrm{SO}_{4}^{-1}$ in a precipitation amount of $1000 \mathrm{~mm}$ which is typical of observations of rainfall for the west coast of Britain. Typically, these sites exhibit precipitation sulfate concentrations of $15-20 \mu$ eq $\mathrm{SO}_{4}$ $\mathrm{L}^{-1}$ in close agreement with the model calculations (28).

Model-derived total sulfur deposition from international shipping peaks at just over $400 \mathrm{mg} \mathrm{S} \mathrm{m}^{-2} \mathrm{yr}^{-1}$ over the North Sea and the Baltic Sea. Deposition levels are above $200 \mathrm{mg}$ $\mathrm{S} \mathrm{m}^{-2} \mathrm{yr}^{-1}$ over the southwestern approaches to the British Isles and Brittany. Expressed as a percentage of total sulfur deposition, the contribution from international shipping approaches $50-55 \%$ in the southwestern approaches. The total sulfur deposition derived here from international shipping (Fig. 1b) across the British Isles falls in the range $40-400$ $\mathrm{mg} \mathrm{S} \mathrm{m}{ }^{-2} \mathrm{yr}^{-1}$, equivalent to sulfate in precipitation levels of about $2.5-25 \mu$ eq $\mathrm{SO}_{4} \mathrm{~L}^{-1}$.

On this basis, it is concluded that international shipping emissions make a significant contribution to model calculated total sulfur deposition along the Atlantic Ocean seaboard of Europe. 

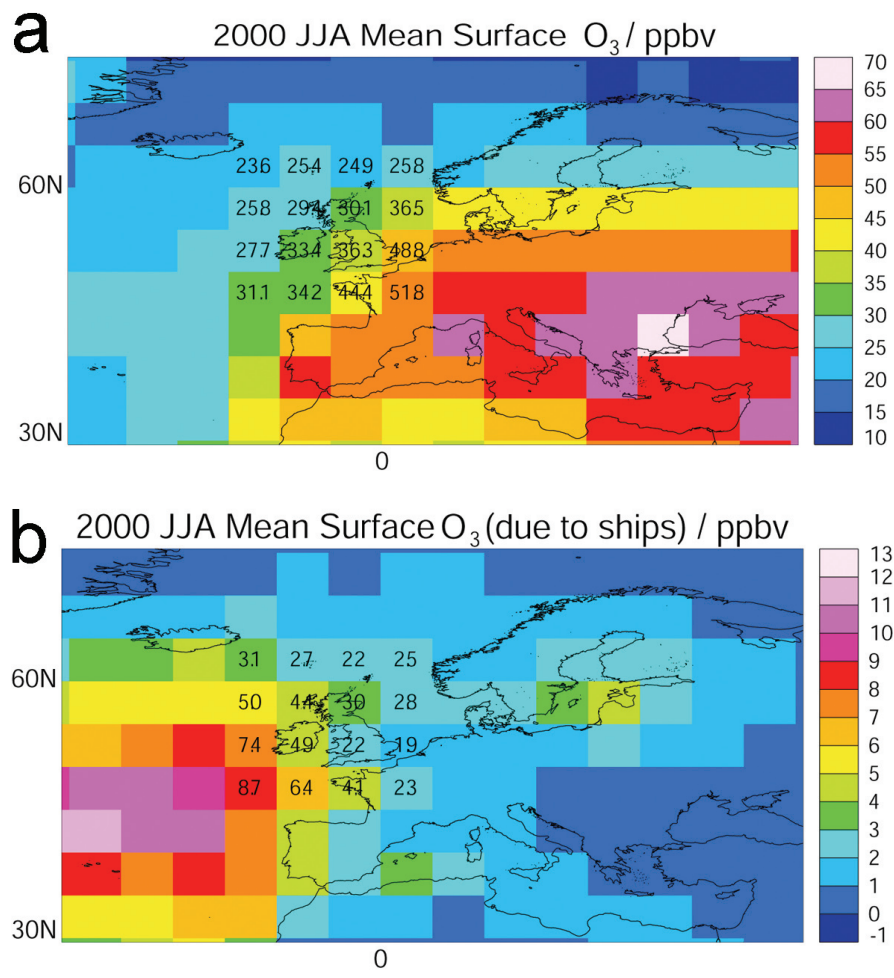

Figure 2. The distribution of mean surface ozone levels during the summer months for Europe calculated for a) all ozone precursor sources; and b) from international shipping alone.

\section{OZONE FORMATION FROM INTERNATIONAL SHIPPING}

In previous work we have shown that, in addition to internal photochemical production within Europe, import of ozone occurs from the global tropospheric background and this represents an important additional ozone source within Europe (30). This transport generally takes place across the North Atlantic Ocean and brings ozone into Europe from the stratosphere, from North America and from Asia (1). Figure $2 \mathrm{a}$ presents the model calculated distribution of surface ozone across Europe and averaged over the summer months (June, July, and August). This ozone distribution was calculated with emissions of ozone precursors from all man-made and natural sources for the year 2000 .

The model calculated surface ozone distribution (Fig. 2a) shows peak levels of over $60 \mathrm{ppb}$ in southern Europe and above $55 \mathrm{ppb}$ in southern Spain. Ozone levels over much of Spain, France, Germany and Central Europe reach and exceed $50 \mathrm{ppb}$ due to internal photochemical ozone production. Over the British Isles, levels exceed $30 \mathrm{ppb}$ and over northern Europe, $40 \mathrm{ppb}$. A ridge of elevated ozone levels crosses the North Atlantic Ocean, extending towards the British Isles at the $25 \mathrm{ppb}$ level. This is identified as an indication of intercontinental ozone transport.

The model calculated surface ozone distribution due to international shipping is displayed in Figure 2b. It was calculated as the difference between two model calculations, one with all precursor sources both man-made and natural and the other with international shipping emissions excluded. This distribution is entirely different spatially to that in Figure 2a. The contribution from international shipping shows a maximum of over $10 \mathrm{ppb}$ in the middle of the North Atlantic Ocean and drops off to about $6 \mathrm{ppb}$ over Ireland, Brittany and Portugal. There are two subsidiary maxima, one in the Mediterranean region and the other over the Baltic Sea. The percentages of the summertime mean ozone concentrations attributable to international shipping vary from over $25 \%$ at the southwestern
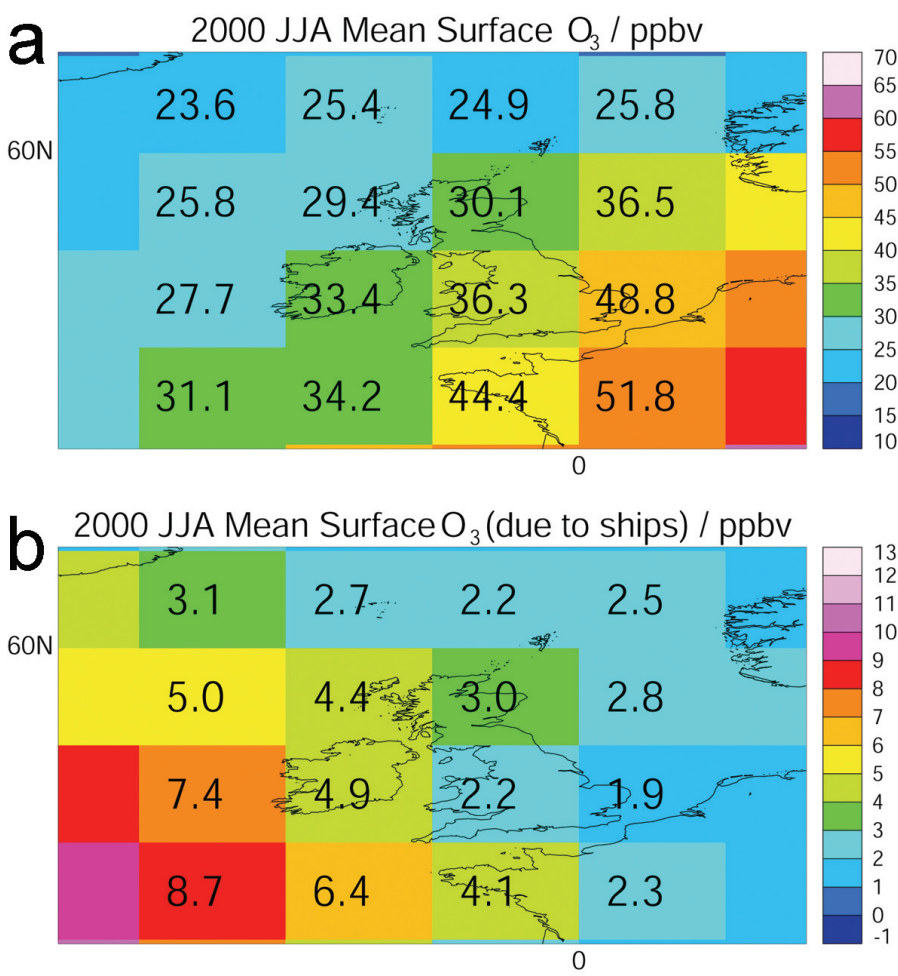

Figure 3. The distribution of mean surface ozone levels during the summer months for the British Isles calculated for a) all ozone precursor sources; and b) from international shipping alone.

tip of Ireland, 15\% over the Western Isles, 9\% over Brittany, and about $5 \%$ over the rest of northwestern Europe. These contributions are similar in both spatial distribution and magnitude to those reported by Endresen et al. (7).

The features of the surface ozone distributions over the British Isles are presented in some more detail in Figures 3a and $b$. International shipping emissions contribute about 2.2 ppb out of $36.3 \mathrm{ppb}(6 \%)$ during summertime over England, 3.0 out of $30.1 \mathrm{ppb}(10 \%)$ over Scotland and $4.9 \mathrm{ppb}$ out of $33.4 \mathrm{ppb}(15 \%)$ over the Republic of Ireland.

On this basis, it is concluded that the contribution to summertime mean ozone concentrations from international shipping is significant along the Atlantic Ocean seaboard of Europe. Furthermore, it is found to be comparable with estimations for intercontinental transport in our previous study (1). International shipping therefore acts as a major external influence on Europe's air quality and contributes to the exceedance of ozone critical levels set for the protection of crops and vegetation, and of air quality guidelines set for the protection of human health.

\section{DISCUSSION AND CONCLUSIONS}

This study, in agreement with those of Jonson et al. (6), and Endresen et al. (7), has demonstrated that the $\mathrm{SO}_{2}$ emissions derived from international shipping also contribute significantly to total sulfur deposition across the Atlantic Ocean seaboard, the North Sea and the Baltic Sea. In a recent comprehensive report on acidification problems within the British Isles (28), an analysis of the trends in the sulfate concentrations in precipitation at 32 monitoring sites over the 12-year period from 1986-1997 revealed marked spatial variations. In contrast to the monitoring sites in central and eastern England, those sites on the Atlantic Ocean seaboard of the British Isles showed no trend in the sulfate concentrations in precipitation despite the $50 \%$ decline in $\mathrm{SO}_{2}$ emissions from the United Kingdom and the rest of Europe over 
the same period. The suggestion was made that the downward trend due to land-based emissions controls may have been offset by an increase in deposition due to increased long-range transport of sulfur from North America and an increased contribution from international shipping. At the time of the NEGTAP (28) report, the precise effect of changes in shipping emissions with time was difficult to quantify as $\mathrm{SO}_{2}$ emissions from shipping could not be disaggregated with much precision. With the analyses completed here, we are able to quantify the role played by international shipping in offsetting the acidification trends due to the reduction in European land-based emissions.

Typically, locations in the Atlantic Ocean seaboard of the United Kingdom over the 1987-1997 period received precipitation sulfate concentrations of $15-20 \mu \mathrm{eq} \mathrm{L} \mathrm{L}^{-1}$. Through the influence of European land-based emission controls, these concentrations would have been expected to have declined to about $8-10 \mu \mathrm{eq} \mathrm{L} \mathrm{L}^{-1}$. The suggestion would then be that this decline had been offset by an increase in deposition amounting to about $7-10 \mu \mathrm{eq} \mathrm{L} \mathrm{L}^{-1}$ over 10 years, equivalent to an increasing trend of $+0.7-1 \mu \mathrm{eq} \mathrm{L} \mathrm{L}^{-1} \mathrm{yr}^{-1}$. This study has demonstrated that international shipping generates total sulfur depositions equivalent to precipitation sulfate concentrations of between 2.5 and $25 \mu \mathrm{eq} \mathrm{L} \mathrm{L}^{-1}$ across the British Isles, using emissions for the year 2000. By re-running the model calculations with emissions for 1990, 2000 and 2010, we have been able to establish the time trends in the contributions from both land-based and international shipping. The latter were found to be $+0.03-0.3 \mu \mathrm{eq}$ $\mathrm{L}^{-1} \mathrm{yr}^{-1}$. So, although international shipping emissions generate about the correct magnitude of contribution across the British Isles, they would not have had the correct magnitude in terms of trends with time to have completely offset the trend due to European land-based emission controls.

Considering the location off the southwestern tip of Ireland in Figure 1, then model total sulfur deposition from all sources decreases from $225 \mathrm{mg} \mathrm{S} \mathrm{m}^{-2} \mathrm{yr}^{-1}$ in 1990 to 207 in 2000 and to 206 $\mathrm{mg} \mathrm{S} \mathrm{m}^{-2} \mathrm{yr}^{-1}$ in 2010. The contribution from land-based sources declines from 123 to 93 and $78 \mathrm{mg} \mathrm{S} \mathrm{m}^{-2} \mathrm{yr}^{-1}$, respectively, whilst that from international shipping steadily increases from 102 to 112 and $128 \mathrm{mg} \mathrm{S} \mathrm{m}^{-2} \mathrm{yr}^{-1}$, respectively, for 1990, 2000 and 2010. Thus, the growth in the contribution from international shipping almost completely offsets the decline due to land-based emission controls. Clearly, this is an extreme case because the chosen location minimizes the sulfur deposition from land-based sources and then maximizes the contribution from international shipping. However, our trends in the growth of international shipping emissions are based on a conservative growth assumption of + $1.25 \% \mathrm{yr}^{-1}$ relative to a base year of 1995 . The growth rate assumed in EDGAR3.2 is $+2.0 \% \mathrm{yr}^{-1}$ over the period 1990-2000, though there is no indication of geographical variation in this assumption. For the contribution from international shipping to have completely offset the trend in sulfur deposition to the Atlantic Ocean seaboard of the British Isles from land-based sources, would have required a growth of $+6 \% \mathrm{yr}^{-1}$ or so which would seem too high. Further consideration of the influence of international shipping emissions on sulfur deposition trends along the Atlantic Ocean seaboard of Europe must therefore await further work on emission projections and future growth rates.

In previous studies with this chemistry-transport model, we have demonstrated the importance of the global ozone background upon which European regional ozone episodes are superimposed (30). Without action on the global scale to control emissions of ozone precursors, future ozone levels may continue to exceed critical levels set to protect crops and air quality guidelines set to protect human health, despite reductions in European precursor emissions. The study of Collins et al. (30) was taken a stage further by Derwent et al. (1) who provided insights into the continent of origins of the global ozone background concentrations observed in Europe. Evidence was presented of substantial contributions to surface ozone levels in Europe from ozone formed over the continents of North America and Asia and advected into Europe by intercontinental transport. On this basis, external influences from North America and Asia appear to be important in determining, in part, the ozone distribution over Europe and potentially how this distribution could respond to actions to control European regional emissions of ozone precursors. Emissions of ozone precursors from Asia are expected to grow in the future, leading potentially to an increasing global ozone background over Europe, with the potential to erode some of the progress to reduce future ozone exposure levels.

Here, in agreement with the study of Endresen et al. (7), we have shown how $\mathrm{NO}_{x}$ emissions from international shipping act as a further external influence on Europe's ozone air quality, particularly during summertime. The expectations are that $\mathrm{NO}_{\mathrm{x}}$ emissions from international shipping will continue to rise in the future, while European land-based $\mathrm{NO}_{\mathrm{x}}$ emissions will decline. International shipping will therefore represent an increasing external influence on Europe's ozone air quality, particularly on the Atlantic Ocean seaboard of Europe. $\mathrm{NO}_{\mathrm{x}}$ emissions from international shipping do not come under the aegis of the Commission of the European Communities and hence they are termed an external influence on Europe's air quality. Control actions, outside of the land-based emissions controls of $\mathrm{SO}_{2}, \mathrm{NO}_{x}$ and VOCs being considered by the EU within their Clean Air For Europe CAFE process will be required, if ozone critical levels and air quality guidelines are to be reached in the future across Europe.

\section{References and Notes}

1. Derwent, R.G., Stevenson, D.S., Collins, W.J., and Johnson, C.E. 2004. Intercontinental transport and the origins of the ozone observed at surface sites in Europe. Atmos. Environ. $38,1891-1901$

2. Lloyd's Register, 1995. Marine exhaust emissions research programme. Lloyd's Register Engineering Services, London.

3. Corbett, J.J., Fischbeck, P.S. and Pandis, S.N. 1999. Global nitrogen and sulfur inventories for oceangoing ships. J. Geophys. Res. 104, 3457-3470.

4. Lawrence, M.G. and Crutzen, P.J. 1999. Influence of $\mathrm{NO}_{\mathrm{x}}$ emissions from ships on tropospheric photochemistry and climate. Nature 402, 167-170

5. Capaldo, K., Corbett, J.J., Kasibhatla, P., Fischbeck, P., and Pandis, S.N. 1999. Effects of ship emissions on sulfur cycling and radiative climate forcing over the ocean. Nature $400,743-746$

6. Jonson, J.E., Tarrason, L., and Bartnicki, J. 2000. Effects of international shipping on European pollution levels. EMEP/MSC-W Note 5/2000. DNMI, Oslo, Norway.

7. Endresen, O., Sorgard, E., Sundet, J.K., Dalsoren, S.B., Isaksen, I.S.A.,, Berglen, T.F., Gravir, G. 2003. Emission from sea transportation and environmental impact, J. Geophys. Res. 108, 4650, doi:10/2002JD002898

8. European Environment Agency, 2002. Annual European Community CLRTAP emission inventory 1990-2000.Technical Report 91_report_2002_73/en.

9. Collins, W.J., Stevenson, D.S., Johnson, C.E., and Derwent, R.G. 1997. Tropospheric ozone in a global-scale three-dimensional Lagrangian model and its response to NOx emission controls, J. Atmos. Chem., 26, 223-274.

10. Sanderson, M. G., Jones, C.D., Collins, W.J., Johnson, C.E., and Derwent, R.G. 2003 Effect of climate change on isoprene emissions and surface ozone levels, Geophys. Res. Lett., 30, 1936, doi:10.1029/2003GL017642.

11. Pope, V. D., Gallani, M.L., Rowntree, P.R. and R. A. Stratton, 2000. The impact of new physical parametrizations in the Hadley Centre climate model: HadAM3, Clim. Dyn. $16,123-146$.

12. Taylor, K.E., Williamson, D. and Zwiers, F. 2000. The sea surface temperature and seaice concentration boundary conditions for AMIP II simulations, PCMDI Report No. 60 (http://www-pcmdi.llnl.gov/pcmdi/pubs/ab60.html), Program for Climate Model Diagnosis and Intercomparison, Lawrence Livermore National Laboratory, Livermore, California.

13. Essery, R., Best, M., Cox, P. 2001. MOSES2.2 Technical Documentation, Hadley Centre Technical Note No. 30 (http://www.metoffice.com/research/hadleycentre/pubs/HCTN), Met. Office, Bracknell, 2001.

14. Collins, W.J., Derwent, R.G., Johnson, C.E., and Stevenson, D.S. 2002. A comparison of two schemes for the convective transport of chemical species in a Lagrangian global two schemes for the convective transport of chemical s
chemistry model. Q. J. R. Meteorol. Soc. 128, 991-1009.

15. Amann, M. 2004. in preparation.

16. Amann, M., Bertok, I., Cofala, J., Gyarfas, F., Heyes, C., Klimont, Z., Makowski, M Schöpp, W. and Syri, S. 1999. Cost-effective Control of Acidification and Ground-Level Ozone - Seventh Interim Report, International Institute for Applied Systems Analysis, Laxenburg, Austria.

17. IPCC, Climate Change 2001: The Scientific Basis. 2001. eds. J. T. Houghton et al., pp 881, Cambridge University Press, UK

18. Cooke, W.F., and Wilson, J.J.N. 1996. A global black carbon aerosol model. J. Geophys Res. 101, 19395-19409.

19. Price, C., Penner, J. and Prather, M. 1997. NO from lightning 1. Global distribution based on lightning physics, J. Geophys. Res., 102, 5929-5941.

20. Meijer, E.W., van Velthoven, P.F.J., Brunner, D.W., Huntrieser, H., and Kelder, H.M. 2001. Improvement and evaluation of the parametrisation of nitrogen oxide production by lightning. Phys. Chem. Earth, 26, 577-583. 
21. Henderson, S.C., Wickrama, U.K., et al. 1999. Aircraft Emissions: Current Inventories and Future Scenarios, In: IPCC Special report on Aviation and the global atmosphere, eds. J. E. Penner et al., pp. 290-331, Cambridge University Press, UK.

22. Stevenson, D. S., Johnson, C.E. Highwood, E J., Gauci, V Collins, W.J and Derwent, R.G. 2003. Atmospheric Impact of the 1783-84 Laki eruption: Part I Chemistry modelR.G. 2003. Atmospheric Impact of the

23. Li, D. and Shine, K.P. 1995. A 4-dimensional ozone climatology for UGAMP models, UGAMP internal report, University of Reading, UK.

4. Murphy, D. M., report, University of Reading, UK. Murphy, D. M., and Fahey, D.W. 1994. An estimate of the flux of stratospher
nitrogen and ozone into the troposphere. J. Geophys. Res., 99, 5325-5332.

5. Olivier, J.G.J. and Berdowski, J.J.M. 2001. Global emissions sources and sinks. In Berdowski, J., Guicherit, R. and B.J. Heij (eds) "The Climate System", pp. 33-78. A.A Balkema Publishers/Swets \& Zeitlinger Publishers, Lisse, The Netherlands. ISBN 90 58092550

26. Corbett, J.J. and Koehler, H.W. 2003. Updated emissions from ocean shipping. J. Geophys. Res. 108, 4650, doi:10.1029/2003JD003751

27. Derwent, R.G., Collins, W.J., Jenkin, M.E., Johnson, C.E., and Stevenson, D.S. 2003. The global distribution of secondary particulate matter in a 3-D Lagrangian Chemistry Transport model. J. Atmos. Chem. 44, 57-95.
28. NEGTAP, 2001. Transboundary air pollution: Acidification, eutrophication and groundlevel ozone in the UK. National Expert Group on Transboundary Air Pollution. CEH Edinburgh, ISBN 187039361 9, Edinburgh.

29. Hjellbrekke, A.-G., Data report 2002. 2002. Acidifying and eutrophying compounds EMEP/CCC-Report 1/2004, Norwegian Institute for Air Research, PO Box 100, NOEMEP

30. Collins, W.J., Stevenson, D.S., Johnson, C.E., and Derwent, R.G. 2000. The European regional ozone distribution and its links with the global scale for the years 1992 and regional ozone distribution and its

31. This study was sponsored by the Air and Environmental Quality Division of the Department for Environment, Food and Rural Affairs through contract no. CPEA 7, by the GMR Programme of the Met Office, by a NERC/Environment Agency Advanced Fellowship (P4-F02) to one of us (DSS) and by the European Commission through contract no; EVK2-CT-2002-80019 NEPAP. The assistance and guidance provided by the referees are gratefully acknowledged.
Richard Derwent is a part-time professor in atmospheric chemistry in the Division of Environmental Science and Technology of Imperial College London. He holds a PhD in physical chemistry from the University of Cambridge. His special interest is in modelling atmospheric chemistry. His address: Imperial College of Science Technology and Medicine, Silwood Park, Ascot, Berkshire, UK.

r.derwent@btopenworld.com

David Stevenson is a NERC/Environment Agency Advanced Research Fellow at the University of Edinburgh, UK. He has a Ph D in Volcanology from the Open University, UK, and an M Sc in Meteorology from the University of Reading, UK. His research focuses on coupled chemistry-climate modelling. His address: Institute of Atmospheric and Environmental Sciences, School of Geosciences, University of Edinburgh, JCMB, King's Buildings, EH9 3JZ, UK.

dstevens@met.ed.ac.uk

Ruth Doherty is a postdoctoral research fellow at the University of Edinburgh, UK. She has a Ph D in Astronomy from the University of Edinburgh, UK and an M Sc in environmental sciences from the University of East Anglia, UK. Her research interests are in the field of climate change and variability and impacts on tropospheric chemistry. Her address: Institute of Atmospheric and Environmental Sciences, School of Geosciences, University of Edinburgh, JCMB, King's Buildings, EH9 3JZ, UK.

ruth@met.ed.ac.uk

William Collins is a senior scientist in the Climate, Chemistry and Ecosystems group of the Met Office's Hadley Centre. His special interest is modelling atmospheric chemistry, with a focus on the impacts of climate change on future atmospheric composition. His address: Hadley Centre, Met Office, FitzRoy Rd. Exeter, UK.

bill.collins@metoffice.gov.uk

Michael Sanderson is an atmospheric chemistry modeller in the Climate Research process at the Met Office, Exeter. He holds a Ph D in chemistry from the University of York. His special interest is in atmosphere-vegetation interactions, and representing these in threedimensional climate-chemistry models. His address: Met Office, Fitzroy Road, Exeter, EX1 3PB.

michael.sanderson@metoffice.gov.uk

Colin Johnson is a researcher at the Hadley Centre. He holds a PhD in Environmental Physics from Nottingham University. His special interest is in modelling the interaction between atmospheric chemistry and climate. His address: Hadley Centre, Met Office, Fitzroy Road, Exeter, EX1 3PB, UK.

colin.johnson@metoffice.gov.uk
Janusz Cofala is a senior research scholar in the Transboundary Air Pollution Programme of the International Institute for Applied Systems Analysis in Laxenburg, Austria. He holds a Dr. Sc. degree in energy economy from the Technical University in Gliwice, Poland. His special interest is in integrated assessment of air pollution control strategies. His address: International Institute for Applied Systems Analysis, 2316 Laxenburg, Austria. cofala@iiasa.ac.at.

Reinhard Mechler is an economist and research scholar in the Risk, Modelling and Society Project of the International Institute for Applied Systems Analysis in Laxenburg, Austria. He holds a Ph.D. in economics from the University of Karlsruhe, Germany. In his research, he has been focusing on the costs, impacts, and benefits of reducing the effects of air pollution and climate change. His address: International Institute for Applied Systems Analysis, 2316 Laxenburg, Austria. mechler@iiasa.ac.at

Markus Amann is leader of the Transboundary Air Pollution Program and co-leader of IIASA's Greenhouse Gas Initiative. He also serves as the head of the Centre for Integrated Assessment Modelling (CIAM) of the European Monitoring and Evaluation Programme (EMEP) under the Convention on Long Range Transboundary Air Pollution (CLRTAP). Under Dr. Amann's leadership, the RAINS integrated assessment model for air pollution has been developed and implemented for Europe and Southest Asia. His research interests include the interface between science and policy and methods for the integrated assessment of environmental issues. His address: International Institute for Applied Systems Analysis (IIASA) A-2361 Laxenburg, Austria. amann@iiasa.ac.at

Frank Dentener is a senior scientist at the Joint Research Centre institute for Environment and Sustainability in Ispra, Italy. He holds a Ph D in Physics. His special interest is modelling of atmospheric chemistry. His address: Joint Research Centre, Institute for Environment and Sustainability Climate Change Unit, TP280, I-21020 Ispra (Va), Italy. frank.dentener@jrc.it 